ORIGINAL ARTICLE / ARTIGO ORIGINAL

\title{
Survival time and distance to access specialized treatment among people living with HIV/Aids in the state of Alagoas, Brazil
}

\author{
Tempo de sobrevida e distância para acesso a tratamento especializado por \\ pessoas vivendo com HIV/Aids no estado de Alagoas, Brasil
}

\author{
Géssyca Cavalcante de Melo' (D), Aline Carla Araújo Carvalho' (D), Anderson da Silva Moreira' (D), \\ Julya Thereza dos Santos Paixão' (iD
}

\begin{abstract}
Objective: To evaluate the effect of the distance between the place of residence and the specialized treatment service on the survival time of people living with HIV/Aids in Alagoas, Northeast Brazil. Methods: Data from the notification and mortality systems related to individuals aged 13 years or older diagnosed with the infection between 2007 and 2013 were used. The cases were observed for a period of follow-up until December 2017. For the analyses, the Pearson's $\chi 2$ test, Kaplan-Meier method, and Cox regression were adopted according to the outcome of the case, place of residence, distance to the health unit, population size of the municipality of residence, sex, skin color/ethnicity, and age. Results: Of the 2,732 analyzed cases, 760 individuals died of Aids-related causes. The average estimate of survival time for individuals residing in the capital was 98.6 months (95\%CI 96.1-101). Among residents of inland cities, the estimate was 92.7 months (95\%CI 89.3-96.1). There was a significant difference in curves throughout the period. The group residing in inland municipalities and those traveling a distance of $>70 \mathrm{~km}$ had a higher average relative risk of death $(\mathrm{RR}=1.21,95 \% \mathrm{CI} 1.05-1.4$ and $\mathrm{RR}=1.18,95 \% \mathrm{CI} 1.01-1.39$, respectively). Conclusion: Living in or near the capital decreases the average relative risk of death. In order to increase the survival time of HIV/Aids patients in Alagoas, it is suggested to decentralize specialized health care, that is, to create regional centers to care for these people.
\end{abstract}

Keywords: HIV. Acquired immunodeficiency syndrome. Survival analysis. Mortality. Health services accessibility. Health status disparities.

'Universidade Estadual de Ciências da Saúde de Alagoas - Maceió (AL), Brazil.

Corresponding author: Géssyca Cavalcante de Melo. Centro de Ciências da Saúde, Universidade Estadual de Ciências da Saúde de Alagoas. Rua Dr. Jorge de Lima, 113, Trapiche da Barra, CEP: 57010-300, Maceió, AL, Brazil. E-mail: gessyca.melo@uncisal.edu.br Conflict of interests: nothing to declare - Financial support: none. 
RESUMO: Objetivo: Avaliar o efeito da distância entre o local de residência e de tratamento especializado sobre o tempo de sobrevida de pessoas vivendo com HIV/Aids em Alagoas, Nordeste do Brasil. Métodos: Utilizaram-se dados dos sistemas de notificação e mortalidade relacionados a indivíduos com idade $\geq 13$ anos diagnosticados com a infecção entre 2007 e 2013. Os casos foram observados por um tempo de seguimento até dezembro de 2017. Para as análises, foram adotados o teste $\chi^{2}$ de Pearson, o método Kaplan Meier e a regressão de Cox, de acordo com o desfecho do caso, o local da moradia, a distância até a unidade de saúde, o tamanho populacional do município de residência, o sexo, a cor/etnia e a idade. Resultados: Dos 2.732 casos analisados, 760 evoluíram para óbito por causas relacionadas à Aids. A estimativa média do tempo de sobrevida dos indivíduos residentes na capital foi de 98,6 meses (intervalo de confiança de 95\% - IC $95 \% 96,1$ - 101). Entre os residentes nos municípios do interior, a estimativa foi de 92,7 meses (IC95\% 89,3-96,1). Houve diferença significativa nas curvas em todo o período. O grupo residente no interior e o daqueles que viajavam a uma distância $>70 \mathrm{~km}$ apresentaram razão de risco $(\mathrm{RR})$ médio de óbito maior ( $\mathrm{RR}=1,21$, IC95\% 1,05 - 1,4; e RR = 1,18, IC95\% 1,01 - 1,39, respectivamente). Conclusão: Residir na capital ou próximo dela diminui o risco relativo médio de óbito. A fim de aumentar o tempo de sobrevida dos pacientes com HIV/Aids em Alagoas, sugere-se descentralizar a assistência especializada, ou seja, criar centros regionais para atendimento dessas pessoas.

Palavras-chave: HIV. Síndrome da imunodeficiência adquirida. Análise de sobrevida. Mortalidade. Acesso aos serviços de saúde. Disparidades nos níveis de saúde.

\section{INTRODUCTION}

Infection with the Human Immunodeficiency Virus (HIV) is a major public health problem worldwide. It is estimated that 37.9 million people live with the virus. Latin America is considered the third most affected global region, in which about a quarter of individuals with HIV do not know their diagnosis and $40 \%$ have no access to antiretroviral therapy ${ }^{1}$.

Globally, Brazil has been prominent in the infection treatment scenario due to the free antiretroviral treatment protocols of universal access. In the same period, the Northeast region recorded 55,090 cases (18.3\%) and, with the exception of the state of Bahia, all of its states showed an increase in the detection rate ${ }^{2}$.

Similarly, data related to the mortality of people living with HIV/Aids (PLWHA) do not follow a uniform trend between Brazilian regions. Between 2008 and 2018, there was a reduction from 5.8 to 4.4 deaths per 100 thousand inhabitants in the country. Nevertheless, in the North and Northeast regions, there was an increase of 26.0 and $2.8 \%$ in this coefficient, respectively ${ }^{2}$.

In the state of Alagoas, specifically, there was an increase of more than $70 \%$ in the Aids detection rate in 2018, with a record of 17.5 cases per 100 thousand inhabitants. In the same year, 583 cases of HIV and 126 deaths from Aids as the underlying cause were reported. Still in 2018, the capital of the state of Alagoas, Maceió, was classified in the $12^{\text {th }}$ position in the national ranking of the detection rate, with 31.5 
cases per 100 thousand inhabitants, and its mortality rate, that same year, was 5.7 crude and standardized ${ }^{2}$.

In addition to the relation to late diagnoses, this information may also indicate that possible missed opportunities for timely treatment are still frequent. Individual barriers for access and retention in health care for PLWHA are also known, such as users' limited financial conditions, low perception of health status, drug use and fear of breaching confidentiality, and discrimination or stigma in the services ${ }^{8-11}$.

However, the specific interference of geographical access, distance, and displacement to healthcare units must be explored, especially concerning areas where the healthcare component of HIV / Aids policies is still developed in specialized services, which are centralized in capitals or regional centers. This factor can contribute to greater programmatic vulnerability to some individuals in relation to others.

In Brazil, there is an incentive on the part of the Ministry of Health to territorialize the follow-up of PLWHA in primary healthcare units. Nevertheless, this decentralization process is still incipient or even nonexistent in some regions, and surrounded by moral, ethical, technical, organizational, and political challenges ${ }^{12}$.

This study aimed to evaluate the effect of the distance between the place of residence and that of specialized treatment services on the survival time of PLWHA in the state of Alagoas, Northeast Brazil.

\section{METHODS}

The state of Alagoas has about 3.3 million inhabitants distributed in 102 municipalities, in an area of 27.8 thousand $\mathrm{km}^{2}{ }^{13}$. At the time considered in this study, the continuous provision of health care to PLWHA at the location was carried out by three specialized outpatient services, all of which located in the capital, Maceió, and linked to a Brazilian Unified Health System (SUS) program.

Records from the Information System on Notifiable Diseases (Sistema de Informação de Agravos de Notificação - SINAN) and the Mortality Information System (Sistema de Informação sobre Mortalidade - SIM), part of the database of the Health Secretariat of the State of Alagoas, were used. All notifications of HIV/Aids in individuals aged 13 years or older, diagnosed between January $1^{\text {st }}, 2007$ and December 31, 2013, were included, according to the case definition criteria of the Brazilian Ministry of Health (ICD10: B20 to B24). The subjects were observed for a period of follow-up until December 31, 2017 and stratified according to the outcome of the case evolution: live subject or death from Aids-related causes. These causes were considered according to the mention of Aids or disease(s) associated with HIV infection in any blank of the individuals' Death Certificate contained in the SIM.

In this study, the following variables were collected: sex, age group, skin color/ ethnicity, place of residence (municipality registered in the notification), population 
size of the municipality of residence - according to the demographic census of the Brazilian Institute for Geography and Statistics ${ }^{13}(<50,000 ; 50,000$ to 499,000 ; and $>500,000$ inhabitants $)-$, and traveling distance $(\leq 70 \mathrm{~km}$ or $>70 \mathrm{~km}$ ), by car, from the retail center of each municipality to the average of kilometers between specialized services for regular follow-up and treatment. This distance was calculated with the aid of Google Maps and Quantum QGIS software, version 2.18.16. Pearson's $\chi^{2}$ test was used to analyze the association between the outcome of the case and the described variables.

For the analysis of the survival curve, two groups were stratified by municipality of residence at the time of diagnosis (capital and inland municipality) and distance from residence to the healthcare service. The death outcome was calculated by the difference between the date of diagnosis contained in the notification and the date of the event, and median time was later obtained, in months. Cases with other causes of death were deemed censorship. For this analysis, the Kaplan-Meier method and the Log-rank, Breslow, and Tarone-Ware association tests were used.

The Cox's regression model was adopted to calculate the crude and adjusted risk ratios, considering the evolution of the case as a primary outcome variable, the place of residence as a primary exposure variable, and sex and age (mean) as confounding variables. All analyses were performed using the Statistical Package for the Social Sciences (SPSS) software, version 25 , with a $95 \%$ confidence interval $(95 \% \mathrm{CI})$.

This study was authorized by the Research Ethics Committee of Universidade Estadual de Ciências da Saúde de Alagoas - CEP/Uncisal (protocol: 70059217.0.0000.5011), as provided for in the standards of the National Health Council.

\section{RESULTS}

In this study, 2,732 individuals who were diagnosed with HIV/Aids in the study period were analyzed. The mean age was 36 years, ranging from 13 to 94 years; $61.1 \%$ of the individuals are male and $71.3 \%$ are mixed-race. Of the total, $1.5 \%(n=41)$ died from causes unrelated to HIV/Aids infection. The characteristics of patients who remained alive $(n=1,931)$ until 2017 and those who had Aids as the underlying cause of death $(\mathrm{n}=760)$ are shown in Table 1 . There was a statistically significant association between the outcome of the case evolution and all the analyzed variables.

The average survival time for individuals who died of Aids-related causes was 98.6 months (95\%CI 96.1-101) and 92.7 months (95\%CI 89.3-96.1) among residents in the capital and inland municipalities, respectively. For the group residing at a distance of $\leq 70 \mathrm{~km}$ from the specialized service, the average estimate of survival time was 97.5 months (95\%CI 95.2-99.7), and for those residing at a distance of $>70 \mathrm{~km}$, the estimate was 92.7 months (95\%CI 88.3-97.0). There was a significant difference in curves (Figures 1 and 2) between groups throughout the observation period. 
Table 1. Sociodemographic characteristics of individuals notified in the Information System on Notifiable Diseases diagnosed with HIV/Aids, according to the death outcome recorded in the Mortality Information System. Alagoas, Brazil, 2007 to 2017 cohort.

\begin{tabular}{|c|c|c|c|}
\hline & \multicolumn{2}{|c|}{ Death } & \multirow[b]{2}{*}{ p-value } \\
\hline & $\begin{array}{c}\text { No } \\
\mathrm{n}=1,931(71.8 \%)\end{array}$ & $\begin{array}{c}\text { Yes } \\
\mathrm{n}=760(28.2 \%)\end{array}$ & \\
\hline \multicolumn{3}{|l|}{ Place of residence } & 0.012 \\
\hline Capital & $1,254(64.9 \%)$ & $454(59.7 \%)$ & \\
\hline Inland municipality & $677(35.1 \%)$ & $306(40.3 \%)$ & \\
\hline \multicolumn{3}{|l|}{ Population size } & 0.006 \\
\hline$>500,000$ & $1,361(70.5 \%)$ & $488(64.2 \%)$ & \\
\hline 50,000 to 499,000 & $164(8.5 \%)$ & $73(9.6 \%)$ & \\
\hline$<50,000$ & $406(21 \%)$ & $199(26.2 \%)$ & \\
\hline \multicolumn{3}{|c|}{ Distance $(\mathrm{km})$ to the service } & 0.042 \\
\hline$\leq 70$ & $1,480(76.6 \%)$ & $554(72.9 \%)$ & \\
\hline$>70$ & $451(23.4 \%)$ & $206(27.1 \%)$ & \\
\hline \multicolumn{3}{|l|}{ Sex } & 0.000 \\
\hline Men & $1,132(58.6 \%)$ & $504(66.3 \%)$ & \\
\hline Women & 799 (41.4\%) & $256(33.7 \%)$ & \\
\hline \multicolumn{3}{|l|}{ Age group (years) } & 0.000 \\
\hline $13-19$ & $78(4 \%)$ & $14(1.8 \%)$ & \\
\hline $20-29$ & $600(31.1 \%)$ & $154(20.3 \%)$ & \\
\hline $30-59$ & $1,218(63.1 \%)$ & $556(73.2 \%)$ & \\
\hline Over 60 & $35(1.8 \%)$ & $36(4.7 \%)$ & \\
\hline \multicolumn{3}{|l|}{ Skin color/ethnicity } & 0.000 \\
\hline White & $269(13.9 \%)$ & $57(7.5 \%)$ & \\
\hline Mixed-race & $1,303(67.5 \%)$ & $614(80.8 \%)$ & \\
\hline Black & $156(8.1 \%)$ & $35(4.6 \%)$ & \\
\hline Other & $1(0.0 \%)$ & $4(0.5 \%)$ & \\
\hline Unknown & $202(10.5 \%)$ & $50(6.6 \%)$ & \\
\hline
\end{tabular}

An increased average relative risk (RR) of death throughout the period was present for the group residing in the inland municipalities $(R R=1.21,95 \% C I 1.05-1.4, p=0.008)$ as well as for individuals who traveled a distance of $>70 \mathrm{~km}(\mathrm{RR}=1.18,95 \% \mathrm{CI} 1.01-$ $1.39, \mathrm{p}=0.041)$. Furthermore, the risk of death at $12,36,60$, and 120 months remained constant $(\mathrm{RR}=1.04,1.04,1.06$, and 1.08 , respectively).

In the multivariate analysis (Table 2 ), the average risk remained similar and significant when considering male individuals $(\mathrm{RR}=1.25,95 \% \mathrm{CI} 1.05-1.48)$ and age $(\mathrm{RR}=1.03,95 \% \mathrm{CI} 1.02-1.03)$ 


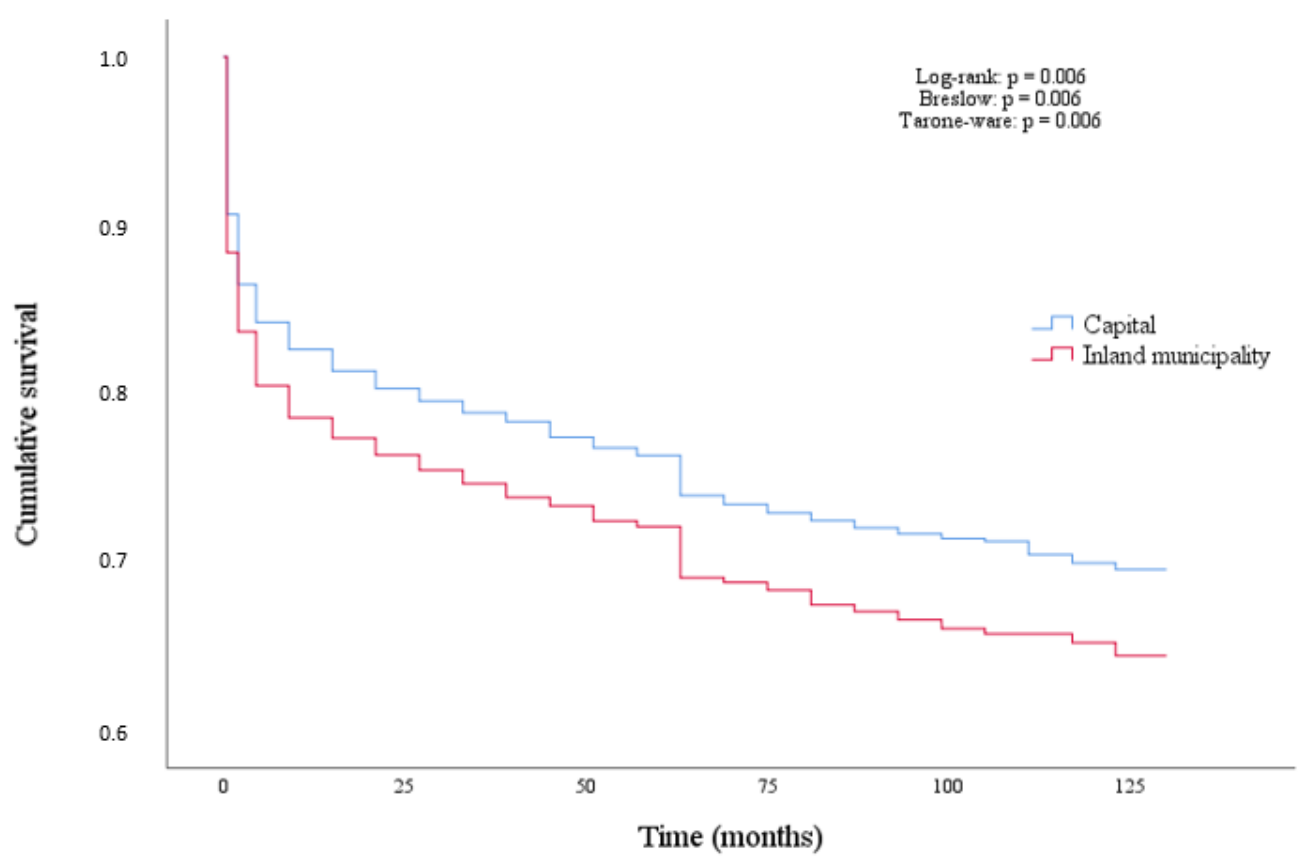

Figure 1. Survival curve of individuals notified in the Information System on Notifiable Diseases diagnosed with HIV/Aids, according to the geographic location of residence (capital or inland municipalities). Alagoas, Brazil, 2007 to 2017 cohort.

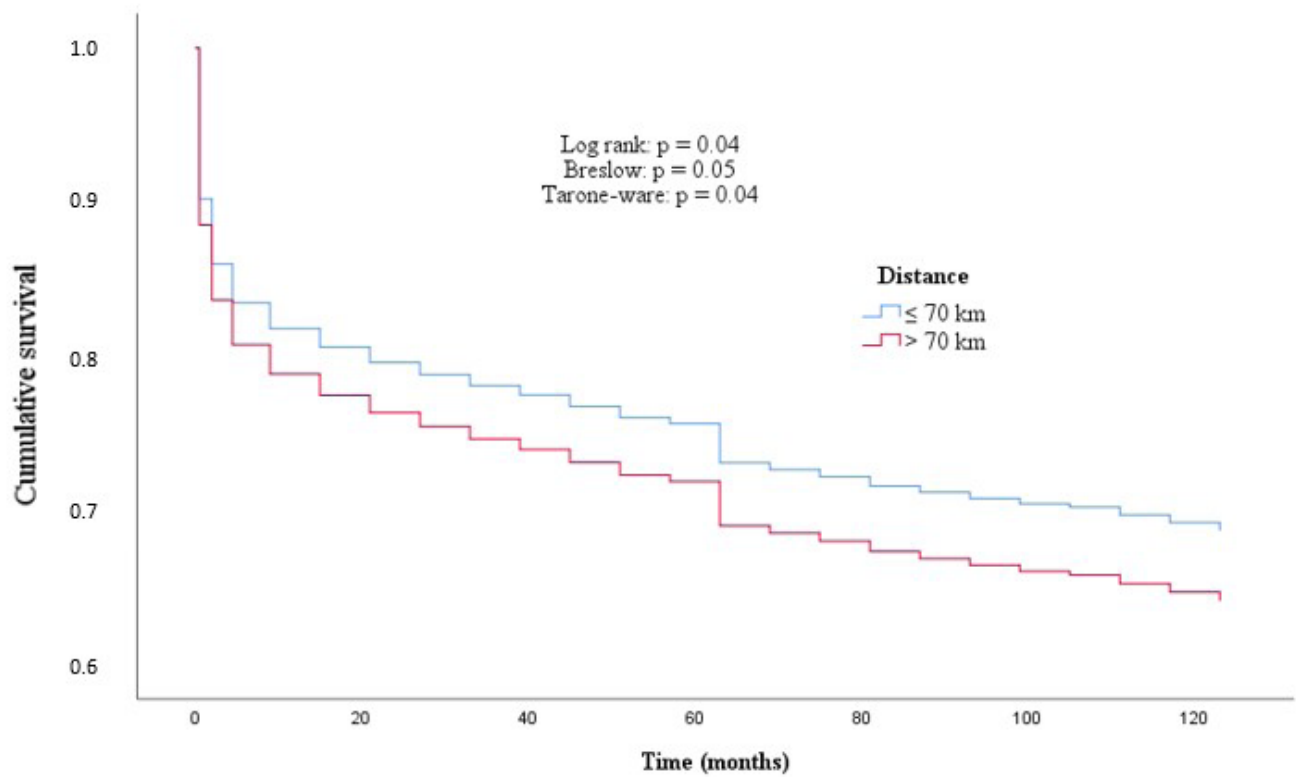

Figure 2. Survival curve of individuals notified in the Information System on Notifiable Diseases diagnosed with HIV/Aids, according to the distance between the municipality of residence and the specialized treatment service. Alagoas, Brazil, 2007 to 2017 cohort. 
Table 2. Association between survival time, place of residence, and personal adjustment variables in individuals notified in the Information System on Notifiable Diseases diagnosed with HIV/Aids. Alagoas, Brazil, 2007 to 2017 cohort.

\begin{tabular}{l|c|c|c|c|}
\hline & $\begin{array}{c}\text { Crude RR } \\
(95 \% \mathrm{Cl})\end{array}$ & p-value & $\begin{array}{c}\text { Adjusted RR } \\
(95 \% \mathrm{Cl})\end{array}$ & p-value \\
\hline Place of residence & \multicolumn{5}{|c|}{} \\
\hline Capital & $1.21(1.05-1.39)$ & 0.008 & $1.27(1.10-1.47)$ & 0.001 \\
\hline Inland municipality & 1.0 Ref & Ref & 1.0 Ref & Ref \\
\hline Sex & 1.0 Ref & Ref & $1.21(0.95-1.55)$ & 0.119 \\
\hline Women & $1.36(1.17-1.57)$ & 0.000 & $1.25(1.05-1.48)$ & 0.014 \\
\hline Men & $1.03(1.02-1.03)$ & 0.000 & $1.03(1.02-1.03)$ & 0.000 \\
\hline Age (mean: 36 years) & &
\end{tabular}

RR: relative risk; $95 \% \mathrm{Cl}$ : 95\% confidence interval.

\section{DISCUSSION}

The data found in this study demonstrated a significant association between the occurrence of deaths, survival time, geographical location of the PLWHA residence, and the distance in relation to specialized healthcare services, even at different time intervals during the observed period and in the models in which the personal characteristics of age and sex were considered.

Regarding the characterization of the sample, there was a higher occurrence of infection in population groups similar to the national profile such as men and young adults $^{2}$. Another study carried out in the Northeast region found characteristics similar to those reported in this research such as the predominance of male, mixed-race individuals, and the age group between 31 and 50 years old ${ }^{14}$. Identifying these aspects allows researchers to know the particularities of the population and its implications for the healthcare process.

It is worth noting that a substantial proportion (18.4\%) of patients in the cohort of this study died during the first 12 months after discovering the infection. Late diagnosis is a possible reason for this result, which was also reported in a research assessing the time of progression from HIV to Aids ${ }^{5,15}$.

In addition, the outcome of death in PLWHA may also be related to other factors of individual, social, and programmatic vulnerability such as being unemployed, using drugs, not undergoing regular treatment, having a history of abandoning treatment, and missing return appointments ${ }^{16}$. Another study addresses factors related to the health-illness dynamics of HIV/Aids such as inequalities, precariousness, discrimination, sexuality issues, justice dilemmas, lack of structure of the healthcare system, and weakness of interpersonal relationships ${ }^{17}$. 
Regarding the estimated survival time found in this study, it is worth emphasizing that, in the considered time interval, Brazil has already adopted the policy of universal access to antiretroviral treatment. However, the initiation of treatment depended on criteria of clinical and immunological deterioration, and it was not adopted for all people diagnosed with HIV. The recommendation to initiate the treatment early, right after diagnosis and regardless of clinical conditions, only started being implemented in the country as of $2014^{18}$.

According to the timeline of advances related to treatment, it can be verified that the survival time of this population has considerably increased. A study on a Brazilian cohort estimated a median survival of 5 months for cases diagnosed in the 1980s; 18 months for those diagnosed in 1995; and 58 months for those diagnosed in $1996^{19}$, whereas the present study estimated a survival of around 98 months.

The distance traveled by the user to the specialized healthcare service was a predictor of this survival time, and a higher risk of death was also evidenced in people living in inland municipalities. When considering the geographic route that must be taken, many individuals have to travel for up to four hours to follow-up at the healthcare unit. Thus, people living distant from the services in this sample may face challenges for accessing health care.

In other situations, the relation between the residence location and distance from the healthcare service of PLWHA has also been associated with loss of follow-up and levels of adherence to antiretroviral treatment in Colombia, with differences in assessments carried out before and after the decentralization of health care ${ }^{20}$. Another study conducted with data from the state of Rio de Janeiro, Brazil, verified lower chances of prenatal care for pregnant women living with HIV when the distance from their residence to the child's birth center was longer ${ }^{21}$.

It is noteworthy that accessibility is a major factor in adherence to treatment and care in HIV/Aids, mainly due to its chronicity. Thus, the centralization of specialized health care associated with the lack of integration with other levels of healthcare services, especially with those that compose the primary care, can hinder the development of actions and strategies for the promotion and prevention aimed at this population.

These results point to the importance of the participation of primary healthcare services (PHC) in the control of morbidity and mortality associated with the infection. In Nigeria, in order to achieve the geographic accessibility of services, health care has been decentralized $^{22}$. In Brazil, as of 2013, the Ministry of Health has also started implementing guidelines and recommendations to encourage the follow-up at primary healthcare services of PLWHA with clinical condition of low risk. Some municipalities with major investments and PHC structure, such as Curitiba and Rio de Janeiro, have effectively started decentralizing the care provided to PLWHA. This allowed PHC to provide services that were previously offered only at secondary and tertiary levels ${ }^{23-25}$.

The reduction in the distance to healthcare services should be considered only as an initial stage, as the transition from this decentralized policy has barriers that have already been described $^{20}$. Potential weaknesses in basic community care can compromise this process, 
especially with regard to the reticence of healthcare providers who are not used to deal with HIV / Aids, the greater turnover of professionals, and incomplete teams. This fact supports the importance of joint management actions in order to qualify the most diverse levels of complexity of healthcare units for the care and subsequent follow-up of HIV cases.

Thus, by understanding that accessibility and retention of PLWHA in the services go beyond the isolated analysis of geographical distance from health care, it is essential for future national research to consider the survey of variables that better explain more subjective issues concerning groups affected by concentrated epidemics and populations vulnerable to other diverse outcomes that increase the rate of morbidity and mortality and that interfere with survival. Aspects, such as the use of psychoactive substances and, especially, gender identity, can be analyzed together with the distance barriers, mainly due to Brazil's urgent need to fulfill the global agenda of zero discrimination.

Some limitations of this study must be observed. The used data are based on records of information systems and, therefore, there is a chance of underreporting of cases and quality imprecision. The incompleteness and lack of other personal information prevented other variables from being included in the analysis. Moreover, the possibility of changing the subjects' residential address was not considered. Nevertheless, the research method was conducted on a large set of data and showed evident significant results. Such information can serve as a basis for comparison with other studies and for planning strategies linked to health policies.

The survival analysis carried out in this study suggests the possibility of disparities in the control of the morbidity and mortality of HIV/Aids infection related to the distance between the geographical locations of people's residencies and access to centralized treatment, and residing in or near the capital is associated with reduction in the average relative risk for death.

Within the scope of these findings, the proximity of the healthcare service to the community through decentralization of the follow-up of PLWHA could contribute to the accessibility of patients at local levels, facilitate the picking up of medications and the use of cost-effective approaches for better access on the part of professionals to take special care of key populations in hard-to-reach areas. In order to increase the survival time of HIV/Aids patients in Alagoas, it is suggested to decentralize specialized health care, which may impact the quality of life of PLWHA.

\section{REFERENCES}

1. UNAIDS. Relatório global do UNAIDS [Internet]. UNAIDS; 2020 [access on Oct. 17, 2020]. Available from: https: / / www.unaids.org/sites/default/files/ media_asset/2020_global-aids-report_en.pdf

2. Brasil. Ministério da Saúde. Epidemiological Bulletin: HIV Aids [Internet]. Brasil: Ministério da Saúde; 2019 [access on Oct. 17, 2020]. Available from: http: / / www. aids.gov.br/pt-br/tags/agravo/hivaids

\footnotetext{
The Antiretroviral Therapy Cohort Collaboration. Survival of HIV-positive patients starting antirretroviral therapy between 1996 and 2013: a collaborative analysis of cohort studies. Lancet HIV [Internet] 2017 [access on May 20, 2020]; 4(8): E349-56. Available from: https: / / doi.org/10.1016/S2352-3018(17)30066-8

4. Cunha R, Maruza M, Montarroyos UR, Coimbra I, Miranda-Filho D de B, Albuquerque $\mathrm{M}$ de F, et al.
} 
Survival of people living with HIV who defaulted from tuberculosis treatment in a cohort, Recife, Brazil. BMC Infect Dis [Internet]. 2017 [access on May 20, 2020]; 17: 137. Available from: https://doi.org/10.1186/ s12879-016-2127-5

5. Poorolajal J, Molaeipoor L, Mohraz M, Mahjub $\mathrm{H}$, Ardekani MT, Mirzapour P, et al. Predictors of progression to AIDS and mortality post-HIV infection: a long-term retrospective cohort study. AIDS Care [Internet]. 2015 [access on May 20, 2020]; 27(10): 120512. Available from: https: / / doi.org/10.1080/0954012 1.2015.1045405

6. Yan H, Yang H, Li J, Wei C, Xu J, Liu X, et al. Emerging disparity in HIV/AIDS disease progression and mortality for men who have sex with men, Jiangsu Province, China. AIDS Behav [Internet]. 2014 [access on May 21, 2020]; 18: 5-10. Available from: https:// doi.org/10.1007/s10461-013-0520-2

7. Mangal TD, Meireles MV, Pascom ARP, Coelho RA, Benzaken AS, Hallett TB. Determinants of survival of people living with HIV/AIDS on antiretroviral therapy in Brazil 2006-2015. BMC Infect Dis [Internet]. 2019 [access on May 21, 2020]; 19: 206. Available from: https: / / doi.org/10.1186/s12879-019-3844-3

8. Flynn AG, Anguzu G, Mubiru F, Kiragga AN, Kamya M, Meya DB, et al. Socioeconomic position and tenyear survival and virologic outcomes in a Ugandan HIV cohort receiving antiretroviral therapy. PLoS One [Internet]. 2017 [access on May 23, 2020]; 12(12): e0189055. Available from: https://doi.org/10.1371/ journal.pone.0189055

9. Sheehan DM, Trepka MJ, Fennie KP, Prado G, Cano MA, Maddox LM. Black-white latino racial disparities in HIV survival, Florida, 2000-2011. Int J Environ Res Public Health [Internet]. 2015 [access on May 23, 2020]; 13(1): 9. Available from: https://doi.org/10.3390/ ijerph13010009

10. Bui HTM, GM Le, Mai AQ, Zablotska-Manos I, Maher L. Barriers to access and uptake of antiretroviral therapy among HIV-positive men who have sex with men in Hanoi, Vietnam: from HIV testing to treatment. Cult Health Sex [Internet]. 2017 [access on May 23, 2020]; 19(8): 859-72. Available from: https://doi.org/10.10 80/13691058.2016.1269203

11. Koirala S, Deuba K, Nampaisan O, Marrone G, Ekström AM. Facilitators and barriers for retention in HIV care between testing and treatment in Asia-A study in Bangladesh, Indonesia, Lao, Nepal, Pakistan, Philippines and Vietnam. PLoS One [Internet]. 2017 [access on May 25, 2020]; 12(5): e0176914. Available from: https: / / doi.org/10.1371/journal.pone.0176914

12. Melo EA, Maksud I, Agostini R. HIV/Aids management at the primary care level in Brazil: a challenge for the Unified Health System? Rev Panam J Salud Publica [Internet]. 2018 [access on May 25, 2020]; 42: e151. Available from: https://doi.org/10.26633/ RPSP.2018.151

13. Instituto Brasileiro de Geografia e Estatística. Portal [Internet]. Brasil: Instituto Brasileiro de Geografia e Estatística; 2018 [access on Dec. 25, 2020]. Available from: https: / www.ibge.gov.br

14. Oliveira EH, Rufino JLN, Verde RMCL, Soares LF, Cabral LO, Vallinoto ACR. Caracterização epidemiológica dos indivíduos portadores do vírus da imunodeficiência humana-1 no estado do Piauí, Brasil. Res Soc Dev [Internet]. 2020 [access on Oct. 22, 2020]; 9(2): e35922002. Available from: https:// doi.org/10.33448/rsd-v9i2.2002

15. Mirzaei M, Poorolajal J, Khazaei S, Saatchi M. Survival rate of AIDS disease and mortality in HIV-infected patients in Hamadan, Iran: a registry-based retrospective cohort study (1997-2011). Int J STD AIDS [Internet]. 2013 [access on May 30, 2020]; 24(11): 859-66. Available from: https: / / doi.org/10.1177/0956462413486457

16. Lopes LM, Andrade RLP, Arakawa T, Magnabosco GT, Nemes MIB, Ruffino Netto A, et al. Vulnerability factors associated with HIV/AIDS hospitalizations: a case-control study. Rev Bras Enferm [Internet]. 2020 [access on Oct. 22, 2020]; 73(3): e20180979. Available from: https: / doi.org/10.1590/0034-7167-2018-0979

17. Maia ECA, Reis Junior LP. Modos de enfrentamento do HIV/Aids: direitos humanos, vulnerabilidades e assistência à saúde. Rev Nufen [Internet]. 2019 [access on Oct. 22, 2020]; 11(1): 178-93. Available from: https: / / doi.org/10.26823/RevistadoNUFEN.vol11.nº1ensaio48

18. Greco DB. Trinta anos de enfrentamento à epidemia da Aids no Brasil, 1985-2015. Ciên Saúde Coletiva 2016; 21(5): 1553-64. https:// doi. org/10.1590/1413-81232015215.04402016

19. Marins JR, Jamal LF, Chen SY, Barros MB, Hudes ES, Barbosa AA, et al. Dramatic improvement in survival among adult Brazilian AIDS patients. AIDS 2003; 17(11): 1675-82. https://doi. org/10.1097/00002030-200307250-00012

20. MacKenzie LJ, Hull MW, Samji H, Lima VD, Yip $\mathrm{B}$, Zhang W, et al. Is there a rural/urban gap in the quality of HIV care for treatment-naïve HIV-positive individuals initiating antiretroviral therapy in British Columbia? AIDS Care 2017; 29(10): 1218-26. https: / / doi.org/10.1080/09540121.2017.1322678

21. Hofer CB, Magalhães MAFM, Frota ACC, Oliveira RH, Abreu TF, Manhães B, et al. HIV Vertical transmission in Rio de Janeiro, Brazil - does the distance matter? AIDS Care [Internet]. 2019 [access on Nov. $1^{\text {st }}, 2020$ ]; 31(3): 314-7. Available from: https://doi.org/10.108 $0 / 09540121.2018 .1515466$ 
22. Oleribe OO, Oladipo OA, Ezieme IP, Crossey MME, Taylor-Robinson SD. From decentralization to commonization of HIV healthcare resources: keys to reduction in health disparity and equitable distribution of health services in Nigeria. Pan Afr Med J [Internet]. 2016 [access on May 29, 2020]; 24: 266. Available from: https://doi.org/10.11604/pamj.2016.24.266.6286

23. Colaço AD, Meirelles BHS, Heidemann ITSB, Villarinho MV. O cuidado à pessoa que vive com HIV/Aids na atenção primária à saúde. Texto Contexto Enferm [Internet]. 2019 [access on Oct. 22, 2020]; 28: 1-14. Available from: https://doi. org/10.1590/1980-265X-TCE-2017-0339

24. Melo EA, Maksud I, Agostini R. Cuidado, HIV/ Aids e atenção primária no Brasil: desafio para a atenção no Sistema Único de Saúde? Rev Panam Salud Publica [Internet]. 2018 [access on Oct. 22, 2020]; 42: e151. Available from: https://doi.org/10.26633/ RPSP.2018.151

25. Zambenedetti G, Silva RAN. Descentralização da atenção em HIV-Aids para a atenção básica: tensões e potencialidades. Physis: Rev Saúde Coletiva [Internet]. 2016 [access on Oct. 22, 2020]; 26(3):
785-806. Available from: https://doi.org/10.1590/ S0103-73312016000300005

Received on: 07/13/2020

Revised on: 11/15/2020

Accepted on: 12/09/2020

Preprint on: 12/14/2020

Authors' contributions: Géssyca Cavalcante de Melo: study conception and design; data collection, analysis and interpretation; writing and critical review of the manuscript; approval of the final version to be published. Aline Carla Araújo Carvalho: study conception and design; data collection, analysis and interpretation; writing and critical review of the manuscript; approval of the final version to be published. Anderson da Silva Moreira: data analysis and interpretation; writing and critical review of the manuscript; approval of the final version to be published. Julya Thereza dos Santos Paixão: data analysis and interpretation; writing and critical review of the manuscript; approval of the final version to be published. 